\title{
CONSEQUENCES OF LEGAL CHANGES FOR THE TOUR OPERATORS' ACTIVITIES IN 2018
}

\author{
ANNA GARDZIŃSKA \\ University of Szczecin, Faculty of Management and Economics of Services, POLAND \\ e-mail: anna.gardzinska@wzieu.pl
}

\begin{abstract}
\begin{tabular}{l|l} 
RECEIVED & 10 December 2018
\end{tabular}
\begin{tabular}{l|l} 
ACCEPTED & 28 December 2018
\end{tabular}

JEL

CLASSIFICATION

Z31, Z32, Z38

KEYWORDS the tourism market, tour operators, the Act on package travel and related tourist services

ABSTRACT Tour operators are important players in the tourism market in regards to the provision of organization and brokerage services. The business activity of tour operators must be adapted to the new legal provisions that entered into force at the beginning of July 2018. On the one hand, the new Act includes provisions that impose more duties on tour operators, and on the other, provides greater protection of clients (tourists). The aim of this article is to indicate changes regulated by law that are essential for the business activities of the tour operators.
\end{abstract}

\section{Introduction}

Tour operators are important players in the tourism market. The basic task of these entities is to combine individual partial services into a coherent whole and offer them to tourist agents in the form of a tourist package. Tour operators carry out activities on their own account, bearing the risk of not selling the offer to the client. Dynamic changes in the national economy and intensive development of services, in particular tourist and financial services, 
as well as continuous expansion of distribution channels, development of the online offer, increasing individualization of package travel and the possibility of selecting and combining various tourist services, necessitated legal changes in the area of tour operators. Provisions regulating the issue of tourist services (both on the basis of Polish and EU law) stopped reflecting the realities of the tourism market.

In July 2018, the Act on package travel and related tourist services entered into force and introduced a number of amendments important for both tour operators and consumers of package travel. The aims of this article are to indicate changes regulated by legal provisions relevant to the business activities carried out by tour operators.

\section{Tour operators as tourism market entitites}

In accordance with the assumptions of the classical economy, the basic and most effective mechanism regulating the functioning of the economy is the market. In the literature on the subject, this term is broadly defined. The market is understood as a place where purchase and sale transactions take place. This term can also be understood as general relations and relationships between buyers, who report demand for goods and services, and sellers, who offer these goods and services, i.e. create supply (Altkorn, 1994, p. 18).

In the case when tourist services are the subject of purchase and sale transactions (single, in the form of tourist packages, or complementary to tourist packages), we are dealing with the tourist services market. As indicated by A. Panasiuk, the tourist services market is an integral part of the tourism market, which, in terms of supply, includes not only tourist services provided mainly by travel companies, but also tourism offer of non-commercial entities, i.e. local government administration units and tourist organizations (Panasiuk, 2014, p. 37).

The functioning of the tourist services market is connected with the occurrence of the following elements (Kurek, 2007, p. 353):

- market entities, i.e. purchasers representing demand and sellers representing supply,

- goods and services that they want to exchange, i.e. exchange market items,

- technical, social and legal conditions for conducting such exchange,

- prices that determine the market value of goods and services as a result of the game of interests between sellers and buyers.

The tour operator market is a part of the tourist services market. Together with the tourism market, it creates an indirect relation through the market of tourist destinations, to which tourist flow, resulting from the provision of services offered at tourist destinations, is directed. The processes of direct consumer (tourists) service are carried out by entities that provide partial services, while the sale of tour operator's services takes place via an intermediary for the sale of tourist services (Panasiuk, 2017, p. 55).

Tour operators, commonly referred to as travel agencies, are specialized entities of the tourism market, who provide services in the scope of organization and sale of package travel (set of services of partial benefit service producers). Organizers of package travel are divided into those offering extensive tourism (popular among a large group of buyers) and the specialized entities, preparing offers for selected, niche segments of demand. On the other hand, a travel agent is understood as a tourist agency which, on the basis of an agency contract, sells or offers for sale package travel created by a tour operator.

The main purpose of tour operators' activities is to tailor the offer to the individual needs of consumers. In order to build a competitive advantage, these entities have to offer unique package travel that stand out from others. The development of online technologies has created a new type of travel agencies that do not employ classic 
forms of direct sales that require personal contact between the client and the employee. For this reason, entities dealing in the organization of package travel are more and more often divided into traditional and online companies.

As a result of the tour operator's actions, the client can purchase a ready-made, bundled set of services, hence freeing themselves from the risk associated with the organization of package travel, which lies on the organizer's side. The purchase of a ready package travel can also save time and money. The total price of the package is usually lower than the sum of partial services, purchased separately by the tourist from the producers. When reporting wholesale demand for tourist services, usually throughout the year or for extended periods, tour operators create economic reasons for calculating prices at a much lower level than in the case of temporary concentration of demand and uncertainty as to the extent to which the potential of the base will be used (Konieczna-Domańska, 2008, p. 134).

\section{Legal conditions for the tour operators' business activities before 1.07.2018}

Tour operator and other enterprises operating in the tourism industry are required to act primarily in accordance with horizontal legal acts regarding running a business in the Polish legal system. The most important legal acts include: the Act on the Tourist Services (Act of 29 August..., 2017), ${ }^{1}$ the Act on Freedom of Economic Activity (Act of 6 March..., 2018), the Civil Code (Act of 13 April ..., 2018), the Commercial Companies Code (Act of 21 April..., 2017), the Act on the National Court Register (Act of 21 April..., 2017), the Act on the Provision of Services in the Territory of the Republic of Poland (Act of 4 March..., 2010) and many others (e.g. regulations on consumer protection, labour law, environmental protection, construction, fire protection, sanitary, tax, insurance).

The most important legal act in force until the end of June 2018 was the Act on Tourist Services, which entered into force on July 1, 1998. Since then, it has been amended 17 times under various legal acts, including three major amendments under the Act amending the Act on Tourist Services in 2000, 2004 and 2010.

Significant problems with the application of the provisions of the Act on Tourist Services arose in 2012, when in the face of insolvency (bankruptcy) of three travel agencies, the amount of financial collateral of travel agencies were insufficient to cover the costs of bringing tourists back to the country or refunding payments for unrealized clients package travel. At that time, the situation prompted the Ministry of Sport and Tourism to carry out an assessment of the Act on Tourist Services. The first stage of the evaluation concerned a consultation in 2013 conducted by representatives of the Ministry of Sport and Tourism with sixteen voivodship marshals and entities from the tourism and banking-insurance industries. On this basis, conclusions were drawn up and material regarding "Analysis of the functioning of the Act on Tourist Services with particular emphasis on the financial security system" prepared (Rekomendacje..., 2013), and submitted at the meeting of the Parliamentary Subcommittee on Tourism on December 13, 2013.

The following stage included an assessment of the Act and the regulations defining the principles of running a business. As part of this study, on the basis of the submitted problems and barriers, recommendations for amendments to the Act on Tourist Services and its implementing acts were prepared, as well as for any other acts that are not within the competence of the Minister of Tourism.

\footnotetext{
${ }^{1}$ The act was in force until June 30, 2018.
} 
The problems related to Act on Tourist Services concerned, first of all, the lack of tools enabling verification, control and monitoring of the financial condition of tour operators and travel intermediaries due to the simplified business registration process.

In the case of running tourist activities in the form of a natural person carrying out business in their own name, the company had to be registered in the Central Register and Information on Economic Activity (CEIDG). In the case of running a business in the form of a partnership or capital company, the company had to be entered in the National Court Register (KRS) (kept by district courts competent for the seat of the established company). As part of simplifying administrative procedures related to running a business, less documents, certificates and attachments to applications from entrepreneurs were required. The registers (KRS and CEIDG) have been publicly available on the Internet since the beginning of 2012, therefore, public administration bodies cannot require entrepreneurs to display, share or attach certificates of entry in CEIDG to their applications.

Another significant problem for tour operators resulted from the unfavourable relation of tour operators and travel intermediaries' ownership capital size to their revenues. The applicable minimum share capital was, according to the entrepreneurs, too high and often constituted a barrier that hindered the commencement of business activities in the form of a capital company. Thus, in 2009 , the requirements regarding the amount of share capital of limited companies were reduced. The applicable share capital in the case of a joint-stock company is PLN 100,000, whereas in the case of limited liability companies it amounts to PLN 5,000.

It should also be emphasized that the provisions of the Accounting Act, in particular the obligation to submit to the relevant court register the annual financial report consisting of, inter alia, the balance sheet and profit and loss account, concern practically only those tour operators and travel intermediaries who operate in the form of commercial companies - which is only little over $20 \%$ of all entrepreneurs.

Lack of sufficient financial collateral funds to cover the costs of bringing customers back to the country or refunding claims for non-performance of the package travel contract, as well as difficulties encountered by marshal offices carrying out the process of bringing insolvent travel agents' customers back to the country, showed that the Act on Tourist Services requires modifications in some key aspects. Furthermore, Poland, as a member state of the European Union, was obliged to implement into its national legislation the Directive (EU) 2015/2302 of the European Parliament and of the Council of 25 November 2015 on package travel and linked travel arrangements, repealing Council Directive 90/314/EEC.

\section{The Act on Package Travel and Related Tourist Services as an example of new tourism legislation}

In 2018, significant changes in tourism legislation that secure consumers of tourist services and regulate the activities of tour operators were introduced. The current Act on Tourist Services, effective from 1 July 2018, changed its name to the Act on Hotel, Tour Leader and Tourist Guide Services (Journal of Laws, No. 133, item 884, 1997). The new wording of the Act specifies only the terms of providing hotel, tour leader and tourist guide services on the territory of Poland, as well as abroad, if contracts with travellers for the provision of these services are concluded in Poland. There were repealed regulations regarding tour operators, travel intermediaries and travel agencies, the Tourist Guarantee Fund, protection of clients, and fines, which were included in the new Act of 24 November 2017 on Package Travel and Related Tourist Services (Journal of Laws, item 2361, 2017). 
The new legal Act specifies the terms of offering sales and implementation of package travel and related tourist services on the territory of Poland, as well as abroad, if travel contracts are concluded by travel companies established in Poland.

The Act introduces significant changes related to the functioning of tour operators, which are presented in Table 1.

Table 1. Selected changes related to the functioning of tour operators on the tourism market

\begin{tabular}{|c|c|}
\hline Extended definition of a tourist service & $\begin{array}{l}\text { Tourist service is widely understood as the carriage of passengers (by air, rail, coach, ferry, ship), } \\
\text { accommodation for other purposes than temporary accommodation, rental of motor cars or other motor } \\
\text { vehicles, as well as other services provided to travellers, existing and provided as a separate service }\end{array}$ \\
\hline $\begin{array}{l}\text { Defining the concept of a tourism } \\
\text { business entrepreneur }\end{array}$ & $\begin{array}{l}\text { Tourism business entrepreneur is a tour operator, an entrepreneur facilitating the purchase of related } \\
\text { tourist services, a tourist agent, or a tourist services provider, being an entrepreneur within the meaning } \\
\text { of Article } 43 \text { of the Act of April } 23,1964 \text { - the Civil Code or conducting activities in return for payment }\end{array}$ \\
\hline Excluding short trips & $\begin{array}{l}\text { The Act does not apply to related travel services lasting less than } 24 \text { hours, unless they include } \\
\text { accommodation. Furthermore, the Act does not apply to related travel services, which are offered and } \\
\text { whose ordering and implementation is facilitated on an occasional and a non-profit-making basis only to } \\
\text { a limited group of travellers, as well as business trips organized on the basis of a general contract }\end{array}$ \\
\hline Travel intermediary as operators & $\begin{array}{l}\text { Under the new Act, travel intermediaries become tour operators who shall be entered into tour operators } \\
\text { and entrepreneurs register facilitating the purchase of related tourist services. The new register replaced } \\
\text { the current register of tour operators and travel intermediaries }\end{array}$ \\
\hline Wider scope of the Act & $\begin{array}{l}\text { The new Act included additional entities that may offer dynamic packages, i.e. package travel and related } \\
\text { travel services (this concerns, for example, tourist accommodation establishments, car rental companies, } \\
\text { airlines which, while offering their services, offer other additional travel services to clients, e.g. field trips) }\end{array}$ \\
\hline $\begin{array}{l}\text { Acceleration of the procedure for } \\
\text { refunding payments or costs incurred } \\
\text { in the event of insolvency of tourism } \\
\text { business entrepreneur }\end{array}$ & $\begin{array}{l}\text { In case of insolvency, tour operators and entrepreneurs who facilitate the purchase of related tourist } \\
\text { services shall immediately inform the voivodship marshal about the situation by submitting the declaration } \\
\text { specified in the Act. In the event of failing to fulfil this obligation and if insolvency is evident in the light } \\
\text { of the circumstances (e.g. in the case of obtaining media information confirmed by travellers), the marshal } \\
\text { of the voivodship has the right to initiate the procedure of organizing the return of travellers to the country } \\
\text { (including the mobilization of financial security) without such a statement }\end{array}$ \\
\hline $\begin{array}{l}\text { The tourist agent's activity does not } \\
\text { require an entry in the register }\end{array}$ & $\begin{array}{l}\text { In accordance with the new Act, an agent is a tourism business entrepreneur other than a tour operator } \\
\text { who, based on an agency agreement, sells or offers for sale package travel created by a tour operator }\end{array}$ \\
\hline $\begin{array}{l}\text { The possibility of printing an entry in the } \\
\text { register from the website }\end{array}$ & $\begin{array}{l}\text { The printout has the same legal value as a document issued by the voivodship marshal, provided it } \\
\text { contains the address of the website on which current information about tourist companies entered in the } \\
\text { register and an identifier allowing confirmation of this printout are posted }\end{array}$ \\
\hline $\begin{array}{l}\text { Clarifying the information obligation for } \\
\text { travellers }\end{array}$ & $\begin{array}{l}\text { If, before the conclusion of the contract for participation in a package travel, information obligations } \\
\text { regarding additional charges or other costs have not been fulfilled, the traveller shall not bear these fees } \\
\text { or costs }\end{array}$ \\
\hline
\end{tabular}

Source: own work.

The new Act contains important provisions from the point of view of tour operators. The concepts of a tourist service, package travel, or tour operators have been redefined, as well as the previously not existing definitions of a tourism business entrepreneur and related tourist services have been introduced. The introduction of the new definition of "a tourism business entrepreneur", comprising, in addition to economic activity, chargeable activity, meant that, among others, non-governmental organizations, educational institutions, sports clubs and parishes that statutorily deal with tourism and sightseeing, support and promote physical culture or activities for children and youth, including leisure, came within the material scope. However, not every trip will be covered by the Act, due to the fact that the act does not apply to package travel carried out on an occasional and a non-profit basis, which is limited only to a group of travellers. Thus, exclusion may, for example, include various forms of local history and tourism (e.g. trips, forest schools, training camps, camps). 
The amendment to the regulations assumes that more entities will have to pay contributions to the Tourism Guarantee Fund. Until now, only travel agencies have been obliged to pay monthly contributions to the fund constituting additional security in the event of bankruptcy of the agency. Moreover, the new Act requires entrepreneurs, who sell the so-called related travel services, to pay premiums, which will result in more people being protected by the fund.

Travel intermediaries have been included in the group of tour operators, a fact that has significant consequences. A travel intermediary, just like any tour operator, will have to meet the appropriate conditions to be able to legally operate on the tourist services market, i.e. maintain financial security in the forms provided for by the law, or provide the marshal of the voivodship with the necessary information on their financial collateral (Bieniek, 2018).

The Act eliminates the mediation of the voivodship marshal both in the procedure of collecting and verifying travellers' declarations, as well as payment of funds from the financial security system and pursuing claims in court, leaving these issues to the exclusive discretion of the travellers. At the same time, the voivodship marshal's competence to demand the funds for implementation of statutory tasks by way of legal proceedings from financial security system institutions was uphold, i.e. the organization of the return of travellers to the country (Bieniek, 2018).

The new regulations that implement the EU directive provide greater protection for tourists. A tour operator or a travel agent is forced to provide full information before entering into a contract with the client, including whereabouts, route, and duration of package travel, means of transport or total cost of the trip. If the contract does not include additional costs (for example, for air-conditioning, TV remote control, mini-bar, towel or sunbed on the beach), the organizer will pay for the expenses. It should be noted that in the Act on Tourist Services from 1997, a tour operator or a travel intermediary were obliged to provide the client with a much smaller scope of information. The travellers did not have to be informed about additional fees and costs if they could not be estimated earlier.

Moreover, the new law introduces a three-year period of limitation on the validity of claims, in the case when the tourist offer does not meet the real conditions. Until now, the customer had 30 days to file a complaint. In the event of unforeseen circumstances at the destination place, which are hazardous to the health or life of tourists, the customer may withdraw from the contract until the departure, without incurring any costs. In addition, a tourist who travels with a travel agency can continue the stay in accordance with the contract, even if the agency goes bankrupt. So far, if the travel agency was becoming insolvent, a tourist was guaranteed a return to the country, but without the possibility of completing the leave.

\section{Conclusions}

Repeatedly amended provisions that have been in force since 1998 stopped reflecting the modern market realities. Such a state of affairs did not provide, among others, customers using package travel with access to comprehensive information on the details of offers and the necessary security in the event of their non-performance, improper performance, or insolvency of travel agencies. The adoption of the Act on package travel and related tourist services was dictated by the need to implement the EU Directive on Package Travel and Related Tourist Services, which updates and extends existing legislation on tourism, and obliges Member States to maximize harmonization in this area.

The Act implements various regulations which will significantly affect the tour operators' activities. Some legal provisions included in the Act raise doubts as to their correct interpretation and the manner of proper implementation. Difficulties of interpretation appear, for example, in Article 46, which contains the wording "minor change" referring 
to the organizer's right to unilaterally change the terms of the contract. However, the Act does not specify when the modification can be considered significant and when minor. The statement about "a clear way of informing the travellers about the change" is also not explained. The operator can only presume whether the clear way of informing is message provided via telephone, e-mail or a formal paper agreement.

Numerous ambiguities resulting from the necessity to apply the new Act by entities dealing with the organization of Package Travel and Related Tourist Services still require numerous consultations or trainings organized by relevant public administration bodies.

\section{References}

Act of 13 April 2018 amending the Act - Civil Code and some other acts, Journal of Laws of 2018, item 1104.

Act of 24 November 2017 on Package Travel and Related Tourist Services, Journal of Laws, item 2361.

Act of 29 August 1997 on tourist services, Journal of Laws of 2017 item 1553 as amended.

Act of 4 March 2010 on the provision of services in the territory of the Republic of Poland, Journal of Laws of 2010, no. 47, item 278.

Act of 21April, 2017 amending the act - the Commercial Companies Code, the Act - Civil Procedure Code and the Act on the National Court Register, Journal of Laws of 2017, item 1133.

Act of March 6, 2018 on the Central Electronic Register and Information on Economic Activity and the Information Point for the Entrepreneur, Journal of Laws of 2018, item 647.

Act on Hotel, Tour Leader and Tourist Guide Services, Journal of Laws of 1997, no. 133, item 884.

Altkorn, J. (1994). Marketing w turystyce. Warszawa: Wydawnictwo Naukowe PWN.

Bieniek, M. (2018). Nowa ustawa i nowe obowiązki dla organizatorów imprez oraz usług powiązanych. Dziennik Gazeta Prawna, 127. Konieczna-Domańska, A. (2008). Biura podróży na rynku turystycznym. Warszawa: Wydawnictwo Naukowe PWN.

Kurek, W. (ed.) (2007). Turystyka. Warszawa: Wydawnictwo Naukowe PWN.

Panasiuk, A. (2014). Rynek turystyczny. Studium strukturalne. Warszawa: Difin.

Panasiuk, A. (ed.) (2017). Regulacja, a orientacja marketingowa touroperatorów. Szczecin: Wydawnictwo Naukowe Uniwersytetu Szczecińskiego.

Rekomendacje do zmian ustawy o usługach turystycznych (2013). Ministerstwo Sportu i Turystyki. Warszawa. Retrieved from: https:// www.msit.gov.pl/pl/turystyka/aktualnosci/2512,Rekomendacje-do-zmian-ustawy-o-uslugach-turystycznych.html.

Cite this anticle aS: Gardzińska, A. (2018). Consequences of legal changes for the tour operators' activities in 2018. European Journal of Service Management, 4 (28/2), 157-163. DOI: 10.18276/ejsm.2018.28/2-19. 